\title{
Shelf life and sensory assessment of tilapia quenelle during frozen storage
}

\author{
Maria Fernanda Calil Angelini(1), Juliana Antunes Galvão(1), Amanda de Freitas Vieira(1), \\ Luciana Kimie Savay-da-Silva ${ }^{(1)}$, Ligianne Din Shirahigue(2), Ingridy Simone Ribeiro Cabral(2), \\ Regina Célia Della Modesta ${ }^{(3)}$, Cláudio Rosa Gallo(1) and Marília Oetterer ${ }^{(1)}$
}

\begin{abstract}
(1)Escola Superior de Agricultura Luiz de Queiroz, Departamento de Agroindústria, Alimentos e Nutrição, Avenida Pádua Dias, no 11, Bairro Vila Independência, CEP 13418900 Piracicaba, SP, Brazil. E-mail: nandaangelini@hotmail.com, jugalvao@usp.br, amandafvieira@ymail.com, kimie@usp.br, crgallo@usp.br, mariliaoetterer@usp.br ${ }^{(2)}$ Centro de Energia Nuclear na Agricultura, Avenida Centenário, no 303, Bairro Agronomia, CEP 13416000 Piracicaba, SP, Brazil. E-mail: shirahigue@cena.usp.br, ingridyribeiro@yahoo.com.br ${ }^{(3)}$ Embrapa Agroindústria de Alimentos, Avenida das Américas, № 29.501, Guaratiba, CEP 23020470 Rio de Janeiro, RJ, Brazil. E-mail: regimode@hotmail.com
\end{abstract}

\begin{abstract}
The objective of this work was to evaluate the shelf life and sensory attributes of tilapia quenelle. Treatments consisted of two types of packages - polyethylene zipper (retort pouch) (QA) and polyethylene waxed paper box $(\mathrm{QB})$ - stored at $-18^{\circ} \mathrm{C}$ for 120 days. Tilapia quenelle was stable for all parameters established by Brazilian legislation. Average values of the evaluated attributes in different packages, during storage, showed no significant difference, except for the "refrigeration" flavor. However, during the storage period, there were significant differences for sensory attributes, as "moist appearance", fish and product aroma, and off flavors of "mud" and "refrigeration". Preserving product quality as for its sensory attributes, during storage, shows that tilapia quenelle is a convenience product and contributes to the increase of fish consumption.
\end{abstract}

Index terms: convenience products, fast food, fish, mechanically separated meat, minced fish.

\section{Vida útil e avaliação sensorial de quenelle de tilápia durante 0 armazenamento em freezer}

\begin{abstract}
Resumo - O objetivo deste trabalho foi avaliar a vida útil e os atributos sensoriais da quenelle de tilápia. Os tratamentos consistiram de dois tipos de embalagens - polietileno com zíper pouch (QA) e polietileno com caixa de papel cartão encerado (QB) - armazenadas a $-18^{\circ} \mathrm{C}$ por 120 dias. A quenelle de tilápia apresentou-se estável quanto aos parâmetros estabelecidos pela legislação brasileira. As médias dos atributos avaliados nas diferentes embalagens, durante o armazenamento, não apresentaram diferenças significativas, exceto quanto ao sabor de "geladeira". No entanto, durante o período de armazenamento, houve diferença significativa quanto aos atributos sensoriais, como "aparência úmida", "aroma de peixe" e "aroma do produto", e sabores não naturais de "barro" e "geladeira". A manutenção da qualidade do produto quanto aos atributos sensoriais, durante o armazenamento, mostra que a quenelle de tilápia é um produto de conveniência e contribui para o aumento do consumo de pescado.
\end{abstract}

Termos para indexação: produtos de conveniência, fast food, pescado, carne mecanicamente separada, polpa de pescado.

\section{Introduction}

Nile tilapia (Oreochromis niloticus) is a tropical climate fish of considerable rusticity for cultivation, with a delicate flavor, and a good quality of nutritional aspects with low fat content and free of Yshaped bones (Medri et al., 2009). For these characteristics this is one of the most cultivated species in the world.

Flesh mechanical separation from fish is called mechanically separated fish meat (MSM) or minced fish (MF). It is an economic and efficient process, which results in higher yield than the filleting process. The mechanical deboning process of fish lacerates the tissues, exposing the cellular components of fish and making the MSM a product highly subjected to deterioration. The process allows to mince fish from different size and weight classes (BiscalchinGryschek et al., 2003). In order to remove pigments, soluble sarcoplasmic proteins, enzymes, some part of lipids and flavor components, mince can be washed in water, thereby increasing its stability and quality while keeping its basic characteristics. The number 
of washings of mince varies according to the desired functional properties and must be sufficient to provide mince stability, during a certain storage period, to avoid loss of fluids while keeping the characteristic flavor of the species (Jesus et al., 2001).

The literature reported studies using MSM in the production of new products like sausages (Moreira et al., 2008; Oliveira Filho et al., 2010, 2012; Marques et al., 2012), mortadella (Moreira et al., 2008), nuggets (Kirschnik \& MacedoViegas, 2009), pâté (Minozzo et al., 2008), croquette (Bordignon et al., 2010), and fish burguer (BiscalchinGryschek et al., 2003).

Quenelle is described in the gastronomy as a product from mechanically deboned meat, using beef, chicken or fish with spices, additives and emulsifier products. Companies may develop products that, in addition to convenience and practicality, must be safe regarding their microbiological and nutritional factors, as well as they should have a good presentation using appropriate packaging.

Packaging has the role to preserve food quality, protecting it from unwanted changes, providing containment, protection, communication and convenience (Han et al., 2005).

There are many types of packaging in the market. Retortpouch is a type of flexible packaging useful for storage because it takes little space. Folding cartons are widely used as retail packaging of food products such as frozen and refrigerated food, convenience food and dietary supplements focused on health (Coles et al., 2003).

The study of a product shelf life provides information on the period that the product maintains its quality and safety features. Such information allows preserving the product's sensory, physical, chemical and microbiological features for food consumption. Product quality is determined with basis on the food integrity during its storage and distribution, taking into account the production, distribution and sale dates (Martins et al., 2008).

Sensory assessment, carried out by qualified tasters, is also used to assess the shelf life of a product, and can be employed at regular intervals during the storage period (Meilgaard et al., 2007). Moreover, it is a tool to assess the product acceptability in the market.

The objective of this work was to assess the shelf life and sensory attributes of tilapia quenelle.

\section{Materials and Methods}

The experiment was conducted in November of 2009. One hundred for individuals of Nile tilapia (Oreochromis niloticus), from a fish farm in São Paulo state, Brazil $\left(23^{\circ} 10^{\prime} 57^{\prime \prime S ~} 46^{\circ} 11^{\prime} 03^{\prime \prime} \mathrm{W}\right)$ were used. Fish average weight was about $550.77 \mathrm{~g}$ each unit, totaling $57.28 \mathrm{~kg}$. Fish were transported in boxes at $0^{\circ} \mathrm{C}$ (ice and fish at 1:1) to the Fish Laboratory, at the Universidade de São Paulo, Piracicaba, SP, Brazil. The animals were slaughtered by hypothermia, washed, scaled, and had their skin removed; they were also gutted, decapitated, and processed using a deboning machine, model HT100C (High Tech Equipamentos Industriais Ltda., Chapecó, SC, Brazil), to obtain mechanically separated fish meat (MSM) (BiscalchinGryschek et al., 2003).

MSM was washed with filtered water, at approximately $10^{\circ} \mathrm{C}$, using $3 \mathrm{~L}$ water per $\mathrm{kg}$ of MSM. This mixture was manually stirred for $3 \mathrm{~min}$, rested for $3 \mathrm{~min}$, and were then filtered through sterilized cotton bags, which were pressed manually to remove the excess water; sobrenadant lipids were not removed. Sodium erythorbate $(0.1 \%)$ and pure sodium tripolyphosphate $(0.5 \%)$ were added to the minced meat (Kirschnik \& MacedoViegas, 2009). The mince remained under refrigeration at $4 \pm 1^{\circ} \mathrm{C}$, for 12 hours.

The tilapia quenelles were prepared with the addition of minced fish (89.36\%), vegetable fat (5.36\%), dried onion $(1.79 \%)$, soy protein isolate $(0.89 \%)$, dried parsley $(0.18 \%)$, 'Hondashi' $(1.79 \%)$, annatto (0.36) and salt $(0.27 \%)$. Afterwards, 360 units were handshaped, weighting $40 \mathrm{~g}$ each, and frozen in IQF (individually quick frozen) in a White Martins liquid nitrogen batch freezer, model Kryospray BF100SD (Cryochem Inc., Murrieta, CA, USA) and, then, these units were precooled at $-60^{\circ} \mathrm{C}$. The quenelles were placed in stainless steel trays and thermally monitored by AlmeMo 25909VS thermocouples (Ahlborn Mess und Regelungstechnik GmbH, Holzkirchen, Germany), then, they were fixed at a surface geometric center.

The minimum temperature freezing at $25^{\circ} \mathrm{C}$, at the geometric center of the product, followed the specifications of the regulation of industrial and sanitary inspection of animal products (Riispoa) according to the Agência Nacional de Vigilância Sanitária (2001). After $2025 \mathrm{~min}$, the thermocouples indicated $25{ }^{\circ} \mathrm{C}$, then, the frozen tilapia quenelles were divided into two batches, which were packaged into 30 units of pouch polyethylene zipper (QA) and into 30 units of waxed 
paper box (QB). Each QA and QB unit contained six quenelles, totaling $240 \mathrm{~g}$ each one. The QA and QB packages were stored at $-18^{\circ} \mathrm{C}$ for 120 days and were monitored every 30 days.

The physicochemical analyses determined the following variables: $\mathrm{pH}$, through a digital potentiometer Digimed, model DMPH1 (Digimed, São Paulo, SP, Brazil), using $10 \mathrm{~g}$ of ground fish and $10 \mathrm{~mL}$ of distilled water (Pregnolatto \& Pregnolatto, 1985); total volatile base nitrogen (Tvbn), using a methodology adapted from Savay da Silva et al. (2008); thiobarbituric acidreactive substances (Tbars), measured by the extraction in trichloroacetic acid (TCA) (Vyncke, 1970), using the tetramethoxypropane to obtain the linear equation used to calculate the Tbars values $(\mathrm{y}=78.494 \mathrm{x}-0.0024)$; moisture and total lipids (Pregnolatto \& Pregnolatto, 1985); protein using the Kjeldahl method (Johnson \& Ulrich, 1974); ash, determined in a calcination process of organic matter in a muffle furnace at $550^{\circ} \mathrm{C}$ (Pregnolatto \& Pregnolatto, 1985); and the total volume of the sample (Winters \& Tennyson, 2006).

Microbiological analyses were carried out according to the resolution RDC $\mathrm{n}^{\circ} 12$ of $12^{\text {th }}$ January of 2001 (Brasil, 2001) aiming at counting Staphylococcus coagulase positive, Salmonella spp, and thermotolerant coliforms at $45^{\circ} \mathrm{C}$. Counting of total coliforms and psychrotrophic microorganisms were also carried out. For the Salmonella detection, the quick method Test 12 (Biocontrol System, 2005) was used. The other analyses were performed according to Silva et al. (1997).

Physicochemical and microbiological analyses were performed on the raw material (minced fish) prior to product elaboration and, after, on the quenelles during the storage period.

Sensory assessment of quenelles was approved by the Ethics Committee of the Escola de Agricultura Luiz de Queiroz (Esalq/Usp), protocol number 21, published in the circular COET/046.

Sixteen panelists were qualified using recognition tests for odor (oregano toothpaste, cinnamon, almond, clove, coffee, garlic, cheese, vanilla, chocolate, orange, strawberry, banana, anise, lemon, eucalyptus, honey, lavender and basil), texture (hardness), basic tastes (salty, sweet, sour and bitter), and triangular test (salt test). Six panelists were selected to test the sensory attributes of the tilapia quenelles using white ceramic plates, coded with three random digits every 30 days (Meilgaard et al., 2007).

For the sensory tests, the frozen samples were baked for $20 \mathrm{~min}$ at $180^{\circ} \mathrm{C}$ and served at $55-60^{\circ} \mathrm{C}$ to the panelists, who rated the product for: appearance (moisture, homogeneity, overall impression); aroma (typically fish and typically product); texture (tenderness, juiciness and elasticity); flavor (typically fish, spices); salty taste; and off flavors of "mud" and "refrigeration" (Meilgaard et al., 2007).

The attributes were assessed by an unstructured scale of $10 \mathrm{~cm}$, anchored in points at one and nine centimeters respectively indicating weak and strong. Appearance was assessed in an individual cabin under white light, while aroma, texture, flavor, taste and off flavors were tasted under red light.

Data of physicochemical and sensory analyses were subjected to the variance analysis, and the means were compared by the Tukey's test, both at $5 \%$ probability, through the SAS 9.2 program, for the sensory assessment, and Statistic 9.1, for the physicochemical analyses.

\section{Results and Discussion}

The mechanically separated fish meat (MSM), used as a raw material for product elaboration, showed $\mathrm{pH}$ and total volatile base nitrogen (Tvbn) respectively of 6.79 and $7.58 \mathrm{mg} 100 \mathrm{~g}^{-1}$, remaining within the limits established by the legislation for Tvbn (30 mg $\left.100 \mathrm{~g} \mathrm{~g}^{-1}\right)$ and for $\mathrm{pH}$ (6.5) (Brasil, 2001). Tokur et al. (2004) observed similar value for the Tvbn, $8.89 \mathrm{mg} 100 \mathrm{~g}^{-1}$ in tilapia, which agrees with our data.

Tbars values for MSM were $1.12 \mathrm{mg} \mathrm{kg}^{-1}$ malonaldehyde. In contrast, BiscalchinGryschek et al. (2003) and Kirschnik \& MacedoViegas (2009) researched minced fish of tilapia, and founded respectively, 0.14 and $0.16 \mathrm{mg} \mathrm{kg}^{-1}$ malonaldehyde, which were below those values found in the present study; these differences can be attributed to seasonality, reproductive period, amount of lipid (Stevanato et al., 2010), and to feed quality.

Chemical composition analysis of quenelle including moisture, lipids, proteins and carbohydrates did not vary during the 120 days storage (Table 1). The literature reports lower moisture and lipid values than those found in the present study (Tokur et al., 2004; Kirschnik \& MacedoViegas, 2009), as well as protein values (Bordignon et al., 2010). However, other 
authors found higher amounts of protein (Kirschnik $\&$ MacedoViegas, 2009). The differences found in the literature can be attributed to environmental differences of fish physiological state and feed quality.

Tbars values are used to measure the degree of lipid oxidation in meat products and byproducts (Ninan et al., 2008), which is an important parameter to study the shelf life of fish products. There was no significant difference among the treatments, as well as in the interaction time versus treatments, but a significant difference was observed for time (Table 2).

Table 1. Chemical composition of tilapia quenelle storage in polyethylene zipper (retort-pouch) (QA) and polyethylene plus waxed paper box (QB), at $-18^{\circ} \mathrm{C}$, for 120 days $^{(1)}$.

\begin{tabular}{lccccc}
\hline Treatment $^{(2)}$ & Moisture & Protein & Lipid & Ash & Carbohydrate \\
& & $---------------------------(\%)---$ & --------------------- \\
\hline QA & $69.8 \pm 3.2 \mathrm{a}$ & $14.4 \pm 1.5 \mathrm{a}$ & $7.4 \pm 2.0 \mathrm{a}$ & $2.5 \pm 2.4 \mathrm{a}$ & $5.9 \pm 2.7 \mathrm{a}$ \\
QB & $72.0 \pm 5.7 \mathrm{a}$ & $13.1 \pm 2.4 \mathrm{a}$ & $8.3 \pm 0.7 \mathrm{a}$ & $2.3 \pm 0.3 \mathrm{a}$ & $7.6 \pm 6.8 \mathrm{a}$ \\
\hline
\end{tabular}

${ }^{(1)}$ Means followed by equal letters, in the columns, do not differ, by Tukey test, at $5 \%$ probability.

Table 2. Thiobarbituric acid reactive substances (Tbars), in tilapia quenelle storage in polyethylene zipper (retortpouch) (QA) and polyethylene plus waxed paper box (QB), at $-18^{\circ} \mathrm{C}$, for 120 days ${ }^{(1)}$.

\begin{tabular}{ll}
\hline Factors & Tbars $\left(\mathrm{mg} \mathrm{kg}^{-1}\right)$ \\
\hline Treatment & $0.88 \pm 0.63 \mathrm{a}$ \\
QA & $0.72 \pm 0.50 \mathrm{a}$ \\
QB & $0.22 \pm 0.18 \mathrm{~b}$ \\
\hline Time & $1.19 \pm 0.60 \mathrm{a}$ \\
0 & $1.18 \pm 0.28 \mathrm{a}$ \\
30 & $1.06 \pm 0.30 \mathrm{a}$ \\
60 & $0.34 \pm 0.40 \mathrm{~b}$ \\
90 & \\
120 & \\
\hline Time x Treatment & $0.21 \pm 0.21 \mathrm{a}$ \\
QA & $1.39 \pm 0.74 \mathrm{a}$ \\
0 & $1.24 \pm 0.41 \mathrm{a}$ \\
30 & $1.10 \pm 0.32 \mathrm{a}$ \\
60 & $0.45 \pm 0.49 \mathrm{a}$ \\
90 & \\
120 & $0.24 \pm 0.17 \mathrm{a}$ \\
QB & $0.98 \pm 0.44 \mathrm{a}$ \\
0 & $1.13 \pm 0.10 \mathrm{a}$ \\
30 & $1.01 \pm 0.31 \mathrm{a}$ \\
60 & $0.24 \pm 0.34 \mathrm{a}$ \\
90 & \\
120 &
\end{tabular}

Fluctuations in the Tbars values were observed during the period of quenelle storage. The literature presented the same tendency for Tbars values in minced byproducts. Tokur et al. (2004) evaluated the lipid stability in fish burgers of tilapia (Oreochromis niloticus) during eight months of storage at $-18^{\circ} \mathrm{C}$, and observed fluctuations in Tbars values similar to those in the present study. According to the authors, this fluctuation can be explained by the Tbars likelihood to combine with some biological compounds like lipids, pigments, and others in the fish muscle. Ninan et al. (2008) also observed fluctuations in Tbars values in tilapia fish balls stored at $20^{\circ} \mathrm{C}$, for 21 weeks; according the authors the fluctuations could be attributed to the use of spices as ingredients, which could have contributed to the reduction of lipid oxidation because of their antioxidant properties. In the present study, the quenelles were stable to lipid oxidation up to 120 days of frozen storage.

Brazilian legislation does not indicate a limit for lipid oxidation as measured by the Tbars for fishery products (Oliveira Filho et al., 2010). The oxidation of foods is more prone to the formation of toxic compounds such as aldehydes, ketones, alcohols, acids and hydrocarbons (Summo et al., 2006); however, it is important to establish standard limits of Tbars to minced byproducts.

Microbiological analyses of the tilapia quenelles, in both treatments, remained within the standards established by Brazilian legislation (Agência Nacional de Vigilância Sanitária, 2001). The data results were lower than $10^{3} \mathrm{CFU} \mathrm{g}^{-1}$ for Staphylococcus coagulase positive, absent at $25 \mathrm{~g}$ for Samonella spp., and lower than $10^{3} \mathrm{NMP} \mathrm{g}^{-1}$ for thermotolerant coliforms at $45^{\circ} \mathrm{C}$ (Table 3).

The mean count of psychotropic microorganisms decreased during storage, remaining below the

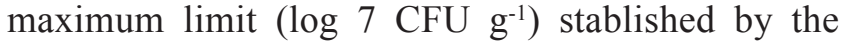
International Commission on Microbiological Specification for Foods (2001). The same behavior was expected and observed for total and thermotolerant coliforms. Ninan et al. (2008) observed similar decreased results in frozen fish balls, during 21 weeks of storage at $20^{\circ} \mathrm{C}$, since freezing generally causes a reduction in bacterial count.

Kirschnik \& MacedoViegas (2009) observed a decrease in the count of psychrotrophic microorganisms, in tilapia nuggets stored for 180 
days at $-18^{\circ} \mathrm{C}$, which was attributed, according to the author, to a heat treatment of the nuggets in the prefreezing pasteurization process.

The mean sensory attributes of quenelles of minced tilapia, stored into different packages (QA and QB) and kept frozen at $-18^{\circ} \mathrm{C}$, showed no significant differences, except for the "refrigeration" flavor (Table 4).

Uniformity values of product appearance, in the two containers, were slightly better than product's moisture, affecting the overall impression of quenelles. Fish aroma was less evident than fish flavor, also desirable product aromas were more pronounced than fish aroma. In terms of texture, elasticity, which is a less desirable attribute, was slightly worse than tenderness and juiciness. Salty taste and spicy flavor met balance, and offflavors, as "mud" and "refrigeration", were quite weak.
Furthermore, when measuring the mean values of all storage days $(0,30,60,90$, and 120$)$ of both packages (QA and QB), it was noted that a significant difference for all attributes took place in the same interaction as packing versus days of storage. Therefore, what influenced sensory product stored at $-18^{\circ} \mathrm{C}$ was the time in which it was stored.

Appearance and aroma attributes of the product behaved similarly, showing the product variation in 30day storage, with a significant decrease at this time. For fish aroma and flavor, loss occurred only at the 90day storage. Texture attributes varied at different times, tenderness and juiciness decreased and increased, respectively, at the 30day storage, and elasticity decreased at the 120day storage. Spicy flavor and offflavors as "mud" and "refrigeration" initiated a significant variation at 30 day storage, with

Table 3. Microbiological parameters evaluated in tilapia quenelle storage in polyethylene zipper retort-pouch (QA) and polyethylene plus waxed paper box (QB), at $-18^{\circ} \mathrm{C}$, for 120 days.

\begin{tabular}{|c|c|c|c|c|c|c|c|c|c|c|}
\hline \multirow{2}{*}{$\begin{array}{l}\text { Storage } \\
\text { period } \\
\text { (day) } \\
\end{array}$} & \multicolumn{2}{|c|}{$\begin{array}{l}\text { Psychrothrophic } \\
(\log \text { CFU g g })\end{array}$} & \multicolumn{2}{|c|}{$\begin{array}{l}\text { Total coliforms } \\
\left(\mathrm{MPN} \mathrm{g}^{-1}\right)\end{array}$} & \multicolumn{2}{|c|}{$\begin{array}{c}\text { Thermotolerant } \\
\left.\text { coliforms (MPN g }{ }^{-1}\right)\end{array}$} & \multicolumn{2}{|c|}{$\begin{array}{c}\text { Staphylococcus coagulase } \\
\text { positive }\left(\mathrm{CFU} \mathrm{g} \mathrm{g}^{-1}\right)\end{array}$} & \multicolumn{2}{|c|}{$\begin{array}{c}\text { Salmonella } \\
(25 \mathrm{~g})\end{array}$} \\
\hline & QA & QB & QA & QB & QA & QB & QA & QB & QA & QB \\
\hline 0 & 3.72 & 4.34 & 29 & 43 & 93 & 23 & $<10$ & $<10$ & absent & absent \\
\hline 30 & 3.84 & 4.41 & $<3.0$ & 3.6 & 3.6 & 3.6 & $<10$ & $<10$ & absent & absent \\
\hline 60 & 3.52 & 4.11 & $<3.0$ & $<3.0$ & 9.2 & $<3.0$ & $<10$ & $<10$ & absent & absent \\
\hline 90 & 4.4 & 4.31 & $<3.0$ & $<3.0$ & 3.6 & 3.6 & $<10$ & $<10$ & absent & absent \\
\hline 120 & 3.25 & 4.21 & $<3.0$ & $<3.0$ & $<3.0$ & $<3.0$ & $<10$ & $<10$ & absent & absent \\
\hline
\end{tabular}

$\log$ CFU g ${ }^{-1}, \log$ of the colony parent unit per gram of product. MPN, most probable number; CFU, colony-forming unit.

Table 4. Sensorial attributes ${ }^{(1)}$ of packaging and storage period of tilapia quenelle in polyethylene zipper (retort-pouch) (QA) and polyethylene plus waxed paper box (QB), at $-18^{\circ} \mathrm{C}$, for 120 days ${ }^{(2)}$.

\begin{tabular}{|c|c|c|c|c|c|c|c|c|c|c|c|c|c|}
\hline \multirow[t]{2}{*}{ Sample } & \multicolumn{3}{|c|}{ Appearance } & \multicolumn{2}{|c|}{ Aroma } & \multicolumn{3}{|c|}{ Texture } & \multirow{2}{*}{$\begin{array}{c}\text { Flavor } \\
\text { Fish }\end{array}$} & \multirow{2}{*}{$\begin{array}{l}\text { Taste } \\
\text { Salt }\end{array}$} & \multicolumn{3}{|c|}{ Flavor } \\
\hline & Moist & Homogeneity & Overall & Fish & Product & Tenderness & Juiciness & Elasticity & & & Spice & Mud & Refrigeration \\
\hline$\overline{\mathrm{QA}}$ & $6.00 \mathrm{a}$ & $7.35 \mathrm{a}$ & $7.55 \mathrm{a}$ & $4.89 a$ & $6.46 \mathrm{a}$ & $6.41 \mathrm{a}$ & $6.74 a$ & $5.53 a$ & $5.21 \mathrm{a}$ & $4.75 a$ & $5.58 \mathrm{a}$ & $1.91 \mathrm{a}$ & $1.86 \mathrm{a}$ \\
\hline QB & $6.02 \mathrm{a}$ & $7.30 \mathrm{a}$ & $7.33 \mathrm{a}$ & $4.96 \mathrm{a}$ & $6.54 \mathrm{a}$ & $6.23 \mathrm{a}$ & $6.78 \mathrm{a}$ & $5.53 \mathrm{a}$ & $5.32 \mathrm{a}$ & $4.80 \mathrm{a}$ & $5.57 \mathrm{a}$ & $1.90 \mathrm{a}$ & $2.07 \mathrm{a}$ \\
\hline \multicolumn{14}{|c|}{ Storage period (days) } \\
\hline 0 & $6.42 \mathrm{a}$ & $7.69 \mathrm{a}$ & $7.72 \mathrm{a}$ & $6.14 \mathrm{a}$ & $7.07 \mathrm{a}$ & $6.50 \mathrm{a}$ & $6.59 b$ & $5.57 \mathrm{a}$ & $5.64 \mathrm{a}$ & $4.87 \mathrm{a}$ & $6.06 \mathrm{a}$ & $1.52 \mathrm{~b}$ & $1.24 b$ \\
\hline 30 & $5.63 \mathrm{ab}$ & $6.81 \mathrm{~b}$ & $7.02 \mathrm{~b}$ & $5.02 \mathrm{a}$ & $5.52 b$ & $6.22 \mathrm{a}$ & $7.06 \mathrm{a}$ & $6.04 \mathrm{a}$ & $5.29 \mathrm{a}$ & $4.62 \mathrm{a}$ & $5.75 b$ & $2.58 \mathrm{a}$ & $2.43 \mathrm{a}$ \\
\hline 60 & $5.01 \mathrm{~b}$ & $7.10 \mathrm{a}$ & $7.11 \mathrm{a}$ & $4.41 \mathrm{a}$ & $6.66 \mathrm{ab}$ & $6.04 \mathrm{a}$ & $6.63 b$ & $5.73 \mathrm{a}$ & $5.00 \mathrm{a}$ & $5.07 \mathrm{~b}$ & $5.61 b$ & $2.07 \mathrm{ab}$ & $2.18 \mathrm{ab}$ \\
\hline 90 & $6.31 \mathrm{ab}$ & $7.41 \mathrm{a}$ & $7.62 \mathrm{a}$ & $3.89 \mathrm{~b}$ & $6.63 \mathrm{ab}$ & $6.03 b$ & $6.61 b$ & $5.48 \mathrm{a}$ & $4.78 b$ & $4.55 \mathrm{a}$ & $5.27 \mathrm{~b}$ & $1.97 \mathrm{ab}$ & $2.21 \mathrm{a}$ \\
\hline 120 & $6.69 \mathrm{a}$ & $7.64 \mathrm{a}$ & $7.72 \mathrm{a}$ & $5.15 \mathrm{a}$ & $6.62 \mathrm{ab}$ & $6.80 \mathrm{a}$ & $6.92 b$ & $4.80 \mathrm{~b}$ & $5.61 \mathrm{a}$ & $4.75 \mathrm{a}$ & $5.21 \mathrm{~b}$ & $1.37 \mathrm{~b}$ & $1.75 \mathrm{ab}$ \\
\hline $\mathrm{F}_{\text {packaging }}$ & $0.01^{\mathrm{ns}}$ & $0.08^{\text {ns }}$ & $2.86^{\mathrm{ns}}$ & $0.22^{\mathrm{ns}}$ & $0.34^{\mathrm{ns}}$ & $2.01^{\mathrm{ns}}$ & $0.15^{\mathrm{ns}}$ & $0.00^{\mathrm{ns}}$ & $1.04^{\mathrm{ns}}$ & $0.17^{\mathrm{ns}}$ & $0.01^{\mathrm{ns}}$ & $0.01^{\mathrm{ns}}$ & $4.50 *$ \\
\hline $\mathrm{F}_{\text {storage day }}$ & $20.13^{*}$ & $3.18^{*}$ & $5.59 *$ & $25.66^{*}$ & $14.17 *$ & $5.30 *$ & $2.80^{*}$ & $4.98 *$ & $9.41 *$ & $2.57^{*}$ & $12.84 *$ & $15.82 *$ & $18.59 *$ \\
\hline $\mathrm{F}_{\text {packagingxstoragexday }}$ & $12.02^{*}$ & $2.43 *$ & $4.08^{*}$ & $7.29^{*}$ & $8.63 *$ & $9.09 *$ & $9.64 *$ & $6.40^{*}$ & $9.03 *$ & $9.33 *$ & $15.96^{*}$ & $7.58^{*}$ & $9.87^{*}$ \\
\hline
\end{tabular}

${ }^{(1)}$ Evaluated by an unstructured scale of $10 \mathrm{~cm}$, anchored in points at one and nine centimeters indicating "weak" and "strong", respectively. (2)Means

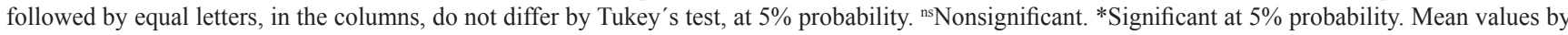
six panelists. 
condiment decrease, and increasing values for "mud" and "refrigeration", with storage.

Significant differences for sensory attributes during the storage days were observed for moist appearance, fish aroma, and product aroma, as well as for offflavors of "mud" and "refrigeration".

In both packages, moist appearance and overall impression had a decrease within 60 days, and an increase up to 120 days of storage; fish aroma decreased up to 90 days, recovering to the similar aroma with 30 days of storage. Product aroma had only one significant drop in 30 days; offflavors of "mud" and "refrigeration" showed a similar behavior: started at very low levels at day zero and repeated them at day 120; in this interval, they increased significantly, but did not reach very high values. The results did not allow differentiating the behavior of individual attributes (Table 5).

Moist appearance and overall impression appearance showed that the product was slightly moister in QA within 120 days of storage; fish aroma and product aroma had the same behavior; only the offflavors of "mud" and "refrigeration" varied for packages: in QA they increased only until the 60 day, and in QB, until the 90 day of storage.

An analysis of all the attributes showed that, if the quenelles in QB became moister after 90 days, the same occurred for juiciness, showing that after 120 days of storage at $-18^{\circ} \mathrm{C}$, the packages allowed an improvement in product quality.

Elasticity should be reduced. At 120day storage, there was a more pronounced reduction of elasticity in $\mathrm{QB}$, which is an improvement of product quality.

Means for fish aroma and fish flavor reduced in both packages until 90 days of storage. Fish aroma was slightly more pronounced in QB, while characteristic fish flavor was more pronounced in QA, recovering after 120 days. However, in QB, a reduction of spicy flavor occurred; which probably explains why fish flavor became more apparent.

A variation of "mud" and "refrigeration" offflavors was more reduced in QA during the storage days, in both packaging, after 90 days.

Many attributes did not show variations during storage; moreover, their averages had been similar for both the treatments. Thus, quenelle preserved in QA showed virtually no changes for the evaluated sensory attributes during the storage period at $-18^{\circ} \mathrm{C}$ for 120 days. However, products maintained in QB, although showing a uniform behavior for various attributes, had the advantage of a visual increase in moist, juiciness, fish aroma, and fish flavor, even with a slight decrease of the spicy flavor.

In general, convenience products for fish market are poorly presented, thus, tilapia quenelle meets innovation and contributes to increase fish consumption of.

Table 5. Sensory analysis ${ }^{(1)}$ of quenelles of minced tilapia stored in polyethylene zipper (retort-pouch) (QA) and polyethylene plus waxed paper box (QB), at $-18^{\circ} \mathrm{C}$, for 120 days ${ }^{(2)}$ (mean values by six panelists)

\begin{tabular}{|c|c|c|c|c|c|c|c|c|c|c|c|c|c|c|}
\hline \multirow[t]{2}{*}{ Sample } & \multirow{2}{*}{$\begin{array}{c}\text { Storage time } \\
\text { (days) }\end{array}$} & \multicolumn{3}{|c|}{ Appearance } & \multicolumn{2}{|c|}{ Aroma } & \multicolumn{3}{|c|}{ Texture } & \multirow{2}{*}{$\begin{array}{l}\text { Flavor } \\
\text { Fish }\end{array}$} & \multirow{2}{*}{$\begin{array}{l}\text { Taste } \\
\text { Salt }\end{array}$} & \multicolumn{3}{|c|}{ Flavor } \\
\hline & & Moist & Homogeneity & Overall & Fish & Product & Tenderness & Juiciness & Elasticity & & & Spice & Mud & Refrigeration \\
\hline \multirow[t]{5}{*}{ QA } & 0 & $6.47 \mathrm{a}$ & $7.60 \mathrm{a}$ & $7.72 \mathrm{a}$ & $6.10 \mathrm{a}$ & $6.67 \mathrm{a}$ & $6.72 a$ & $6.63 a$ & $5.75 \mathrm{a}$ & $5.22 \mathrm{a}$ & $4.95 \mathrm{a}$ & $5.53 \mathrm{a}$ & $1.65 \mathrm{a}$ & $1.10 \mathrm{~b}$ \\
\hline & 30 & $5.94 \mathrm{a}$ & $6.85 a$ & $7.44 b$ & $5.08 \mathrm{~b}$ & $5.57 \mathrm{~b}$ & $6.52 \mathrm{a}$ & $7.17 \mathrm{a}$ & $5.78 \mathrm{a}$ & $5.53 \mathrm{a}$ & $4.86 a$ & $5.77 \mathrm{a}$ & $2.38 \mathrm{~b}$ & $2.36 \mathrm{a}$ \\
\hline & 60 & $5.07 \mathrm{~b}$ & $7.20 \mathrm{a}$ & $7.12 b$ & $4.37 \mathrm{~b}$ & $6.67 \mathrm{a}$ & $5.86 \mathrm{a}$ & $6.70 \mathrm{a}$ & $5.71 \mathrm{a}$ & $4.89 \mathrm{a}$ & $4.85 \mathrm{a}$ & $5.78 \mathrm{a}$ & $2.27 \mathrm{~b}$ & $2.17 \mathrm{ab}$ \\
\hline & 90 & $6.20 \mathrm{a}$ & $7.33 \mathrm{a}$ & $7.70 \mathrm{a}$ & $3.82 \mathrm{c}$ & $6.75 \mathrm{a}$ & $6.05 \mathrm{a}$ & $6.53 \mathrm{a}$ & $5.25 \mathrm{a}$ & $4.65 \mathrm{a}$ & $4.23 \mathrm{a}$ & $5.37 \mathrm{a}$ & $1.75 \mathrm{a}$ & $1.92 \mathrm{a}$ \\
\hline & 120 & $6.35 \mathrm{a}$ & $7.90 \mathrm{a}$ & $7.82 \mathrm{a}$ & $5.18 \mathrm{a}$ & $6.44 \mathrm{a}$ & $6.91 \mathrm{a}$ & $6.66 \mathrm{a}$ & $5.16 \mathrm{a}$ & $5.75 \mathrm{a}$ & $4.85 \mathrm{a}$ & $5.47 \mathrm{a}$ & $1.47 \mathrm{ab}$ & $1.74 \mathrm{ab}$ \\
\hline \multirow[t]{5}{*}{$\overline{\mathrm{QB}}$} & 0 & $6.37 \mathrm{a}$ & $7.78 \mathrm{a}$ & $7.72 \mathrm{a}$ & $6.18 \mathrm{a}$ & $7.27 \mathrm{a}$ & $6.28 \mathrm{a}$ & $6.55 \mathrm{a}$ & $5.40 \mathrm{a}$ & $6.06 \mathrm{a}$ & $4.78 \mathrm{a}$ & $6.58 \mathrm{a}$ & $1.38 \mathrm{a}$ & $1.38 \mathrm{~b}$ \\
\hline & 30 & $5.32 \mathrm{a}$ & $6.77 \mathrm{a}$ & $6.59 b$ & $4.97 b$ & $5.48 b$ & $5.92 \mathrm{a}$ & $6.94 \mathrm{a}$ & $6.30 \mathrm{a}$ & $5.06 \mathrm{a}$ & $4.38 \mathrm{a}$ & $5.72 \mathrm{a}$ & $2.78 \mathrm{~b}$ & $2.51 \mathrm{a}$ \\
\hline & 60 & $4.96 \mathrm{~b}$ & $7.00 \mathrm{a}$ & $7.10 \mathrm{~b}$ & $4.46 b$ & $6.65 \mathrm{a}$ & $6.22 \mathrm{a}$ & $6.57 \mathrm{a}$ & $5.76 \mathrm{a}$ & $5.11 \mathrm{a}$ & $5.30 \mathrm{a}$ & $5.44 \mathrm{a}$ & $1.85 \mathrm{~b}$ & $2.19 \mathrm{ab}$ \\
\hline & 90 & $6.42 \mathrm{a}$ & $7.48 \mathrm{a}$ & $7.53 \mathrm{a}$ & $3.97 \mathrm{c}$ & $6.52 \mathrm{a}$ & $6.02 \mathrm{a}$ & $6.68 \mathrm{a}$ & $5.72 \mathrm{a}$ & $4.92 \mathrm{a}$ & $4.87 \mathrm{a}$ & $5.16 \mathrm{a}$ & $2.18 \mathrm{a}$ & $2.50 \mathrm{a}$ \\
\hline & 120 & $7.04 \mathrm{a}$ & $7.48 \mathrm{a}$ & $7.69 \mathrm{a}$ & $5.22 \mathrm{a}$ & $6.79 \mathrm{a}$ & $6.70 \mathrm{a}$ & $7.28 \mathrm{a}$ & $4.46 \mathrm{a}$ & $5.46 \mathrm{a}$ & $4.65 \mathrm{a}$ & $4.76 \mathrm{a}$ & $1.21 \mathrm{ab}$ & $1.75 \mathrm{ab}$ \\
\hline$F_{\text {packaging }}$ & & $0.00^{\text {ns }}$ & $0.05^{\mathrm{ns}}$ & $1.52^{\mathrm{ns}}$ & $0.05^{\text {ns }}$ & $0.09^{\text {ns }}$ & $0.67^{\mathrm{ns}}$ & $0.07^{\mathrm{ns}}$ & $0.00^{\mathrm{ns}}$ & $0.24^{\mathrm{ns}}$ & $0.04^{\mathrm{ns}}$ & $0.02^{\mathrm{ns}}$ & $0.00^{\mathrm{ns}}$ & $0.94^{\mathrm{ns}}$ \\
\hline $\mathrm{F}_{\text {storage day }}$ & & $4.00^{*}$ & $2.08^{\mathrm{ns}}$ & $2.86^{*}$ & $9.09 *$ & $3.78^{*}$ & $1.77^{\mathrm{ns}}$ & $0.89^{\text {ns }}$ & $1.64^{\mathrm{ns}}$ & $2.16^{\mathrm{ns}}$ & $0.59^{\mathrm{ns}}$ & $1.49^{\text {ns }}$ & $4.51^{*}$ & $3.89 *$ \\
\hline $\mathrm{F}_{\text {packaging xpackaging }}$ & & $0.49^{\text {ns }}$ & $0.17^{\mathrm{ns}}$ & $0.72^{\mathrm{ns}}$ & $0.72^{\text {ns }}$ & $0.22^{\text {ns }}$ & $0.57^{\mathrm{ns}}$ & $0.53^{\mathrm{ns}}$ & $0.55^{\text {ns }}$ & $1.05^{\mathrm{ns}}$ & $0.75^{\mathrm{ns}}$ & $1.17^{\mathrm{ns}}$ & $0.79^{\mathrm{ns}}$ & $0.25^{\mathrm{ns}}$ \\
\hline
\end{tabular}

${ }^{(1)}$ Use of an unstructured scale of $10 \mathrm{~cm}$, anchored in points at one and nine centimeters indicating "weak" and "strong", respectively. (2)Means followed by

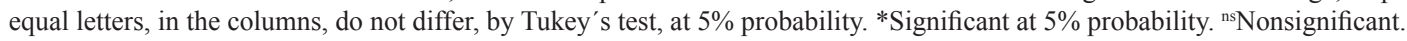




\section{Conclusion}

1. Both polyethylene (retortpouch) and polyethylene bag plus waxed box are viable packages to maintain the shelf life and sensory attributes of tilapia quenelles during frozen storage.

2. The sensory attributes of quenelles are preserved in both packages; however, the packaging of polyethylene bag plus waxed paper box shows a more uniform behavior during storage.

\section{Acknowledgements}

To the Conselho Nacional de Desenvolvimento Científico e Tecnológico (CNPq), for granted scholarship; to Financiadora de Estudos e Projetos (Finep), Fundação de Amparo à Pesquisa do Estado de São Paulo (Fapesp), and Aquabrasil Project, for funding this research. To Mr. Francisco Leão, for providing the samples, to the Extension and Study Group for Technological Innovation and Quality of Fish, Escola Superior de Agricultura Luiz de Queiroz, from Universidade de São Paulo (Getep/Esalq/USP), for support in the analyses and activities.

\section{References}

AGÊNCIA NACIONAL DE VIGILÂNCIA SANITÁRIA. Resolução RDC no 12, de 02 de janeiro de 2001. Aprova o regulamento técnico sobre padrões microbiológicos em alimentos. Diário Oficial [da] República Federativa do Brasil, 02 jan. 2001. BIOCONTROL SYSTEM. Pathogen testing: 12 test Salmonella. 2005. Available at: $<$ http://www.biocontrolsys.com/assets/uploads/ files/12 brochure\%281\%29.pdf>. Accessed on: 20 Jan. 2010.

BISCALCHINGRYSCHEK, S.F.; OETTERER, M.; GALLO, C.R. Characterization and frozen storage stability of minced Nile tilapia (Oreochromis niloticus) and red tilapia (Oreochromis spp.). Journal of Aquatic Food Product Technology, v.12, p.57-69, 2003. DOI: $10.1300 / J 030 v 12$ n03_06.

BORDIGNON, A.C.; SOUZA, B.E. de; BOHNENBERGER, L.; HILBIG, C.C.; BOSCOLO, W.R.; FIEDEN, A. Elaboração de croquete de tilápia do Nilo (Oreochromis niloticus) a partir de CMS e aparas de corte em ' $V$ ' do filé e sua avaliação físicoquímica, microbiológica e sensorial. Acta Scientiarum. Animal Sciences, v.32, p.109-116, 2010. DOI: 10.4025/actascianimsci.v32i1.6909.

BRASIL. Ministério da Agricultura, Pecuária e Abastecimento. Regulamento da inspeção industrial e sanitária de produtos de origem animal - RIISPOA: pescados e derivados. 2001. Cap. 7, seção 1. Disponível em: <http://www.agricultura. gov.br/arq_editor/file/Aniamal/MercadoInterno/Requisitos/ RegulamentoInspecaoIndustrial.pdf >. Acesso em: 25 mar. 2013.
COLES, R.; MCDOWELL, D.; KIRWAN, M.J. Food packaging technology. Oxford: Blackwell, 2003. 346p.

HAN, J.H.; HO, C.H.L.; RODRIGUES, E.T. Intelligent packaging. In: HAN, J.H. (Ed.). Innovations in food packaging. Baltimore: Elsevier, 2005. p.138-155. DOI: 10.1016/B978-0123116321/50041-3.

INTERNATIONAL COMMISSION ON MICROBIOLOGICAL SPECIFICATION FOR FOODS. Pescados y productos derivados. In: INTERNATIONALCOMMISSIONONMICROBIOLOGICAL SPECIFICATION FOR FOODS. Microorganismos de los alimentos 6: ecología microbiana de los productos alimentarios. Zaragoza: Acribia, 2001. p.121-166.

JESUS, R. de S.; LESSI, E.; TENUTAFILHO, A. Estabilidade química e microbiológica de "minced fish" de peixes amazônicos durante o congelamento. Ciência e Tecnologia de Alimentos, v.21, p.144-148, 2001. DOI: 10.1590/S0101-20612001000200004.

JOHNSON, C.M.; ULRICH, A. Analytical methods. In: SARRUGE, J.R.; HAAG, H.P. Análises químicas em plantas. Piracicaba: ESALQ, 1974. 56p.

KIRSCHNIK, P.G.; MACEDOVIEGAS, E.M. Efeito da lavagem e da adição de aditivos sobre a estabilidade de carne mecanicamente separada de tilápia do Nilo (Oreochromis niloticus) durante estocagem a $-18^{\circ} \mathrm{C}$. Ciência e Tecnologia de Alimentos, v.29, p.200-206, 2009. DOI: 10.1590/S010120612009000100031.

MARQUES, L.F.; NUNES, J.S.; CASTRO, D.S.; ARAUJO, L.K.; SALES, M.L.S. Avaliação da qualidade de linguiça de tilápia do Nilo (Oreochromis niloticus). Revista Semiárido de Visu, v.2, p.3-10, 2012.

MARTINS, R.C.; LOPES, V.V.; TEIXEIRA, J.A. Computational shelflife dating: complex systems approaches to food quality and safety. Food and Bioprocess Technology, v.1, p.207-222, 2008. DOI: $10.1007 / \mathrm{s} 1194700800710$.

MEDRI, V.; MEDRI, W.; CAETANO FILHO, M. Growth of Nile tilapia Oreochromis niloticus fed diets with different levels of proteins of yeast. Brazilian Archives of Biology and Technology, v.52, p.721-728, 2009. DOI: 10.1590/S151689132009000300024.

MEILGAARD, M.C.; CIVILle, G.V.; CARR, B.T. Sensory evaluation techniques. $4^{\text {th }}$ ed. Boca Raton: CRC Press, 2007. 453p.

MINOZZO, M.G.; WASZCZYNSKYJ, N.; BOSCOLO, W.R. Utilização de carne mecanicamente separada de tilápia (Oreochromis niloticus) para a produção de patês cremoso e pastoso. Alimentos e Nutrição, v.19, p.315-319, 2008.

MOREIRA, R.T.; LEMOS, A.L. da S.C.; HARADA, M.M.; CIPOLLI, K.; MENDES, E.S.; GUIMARÃES, J.L.; CRISTIANINI, M. Desenvolvimento e aceitação de embutido emulsionado tipo "mortadela" elaborado com tilápia (Oreochromis niloticus L.). Higiene Alimentar, v.22, p.47-53, 2008.

NINAN, G.; BINDU, J.; JOSEPH, J. Frozen storage studies of mince based products developed from tilapia (Oreochromis mossatnbicus, Peters 1852). Fishery Technology, v.45, p.35-42, 2008.

OLIVEIRA FILHO, P.R.C. de; FÁVAROTRINDADE, C.S.; TRINDADE, M.A.; BALIEIRO, J.C. de C.; VIEGAS, E.M. Quality of sausage elaborated using minced Nile tilapia submmitted to cold 
storage. Scientia Agricola, v.67, p.183-190, 2010. DOI: 10.1590/ S010390162010000200009.

OLIVEIRA FILHO, P.R.C. de; VIEGAS, E.M.; KAMIMURA, E.S.; TRINDADE, M.A. Evaluation of physicochemical and sensory properties of sausages made with washed and unwashed mince from Nile tilapia byproducts. Journal of Aquatic Food Product Technology, v.21, p.222-237, 2012. DOI: 10.1080/10498850.2011.590270.

PREGNOLATTO, W.; PREGNOLATTO, N.P. Normas analíticas do Instituto Adolfo Lutz: métodos químicos e físicos para análise de alimentos. 3.ed. São Paulo: Instituto Adolfo Lutz, 1985. 533p.

SAVAY DA SILVA, L.K.; RIGGO, R.; MARTINS, P.E.; GALVÃO, J.A.; OETTERER, M. Otimização e padronização do uso da metodologia para determinação de bases nitrogenadas voláteis totais (BNVT) em camarões Xyphopenaeus kroyeri. Brazilian Journal of Food and Technology, v.20, p.138-144, 2008.

SILVA, N. da; JUNQUEIRA, V.C.A.; SILVEIRA, N.F. de A. Manual de métodos de análise microbiológica de alimentos. São Paulo: Varela, 1997. 295p.

STEVANATO, F.B.; COTTICA, S.M.; PETENUCI, M.E.; MATSUSHITA, M.; DESOUZA, N.E.; VISENTAINER, J.V.
Evaluation of processing, preservation and chemical and fatty acid composition of Nile tilapia waste. Journal of Food Processing and Preservation, v.34, p.373-383, 2010. DOI: 10.1111/j.17454 549.2009.00429. $\mathrm{x}$

SUMMO, C.; CAPONIO, F.; PASQUALONE, A. Effect of vacuumpackaging storage on the quality level of ripened sausages. Meat Science, v.74, p.249-254, 2006. DOI: 10.1016/j. meatsci.2006.03.008.

TOKUR, B.; POLAT, A.; BEKLEVIK, G.; ÖZKÜTÜK, S. Changes in the quality of fishburger produced from tilapia (Oreochromis niloticus) during frozen storage $\left(18^{\circ} \mathrm{C}\right)$. European Food Research and Technology, v.218, p.420-423, 2004. DOI: $10.1007 / \mathrm{s} 0021700408794$.

VYNCKE, W. Direct determination of the thiobarbituric acid value in thichloroacetic acid extracts of fish as a measure of oxidative rancidity. Fette, Seifen Anstrichmittel, v.2, p.1084-1087, 1970. DOI: 10.1002/lipi.19700721218.

WINTERS, S.; TENNYSON, J. Fish and other marine products - ash of seafood. In: HORWITZ, W. (Ed.). Official methods of analysis of AOAC International. $18^{\text {th }}$ ed. Gaithersburg: AOAC International, 2006. p.8.

Received on July 18, 2011 and accepted on June 25, 2013 